\title{
Early Complications after Lung Resections at Patients Treated For Lung Cancer with and Without Neoadjuvant Hemiotheraphy
}

\author{
Goran Kondov ${ }^{1}$, Simonida Crvenova ${ }^{2}$, Zoran Spirovski ${ }^{1}$, Trajanka Trajkovska ${ }^{3}$, Sashko Jovev ${ }^{1}$, Irena Kondova-Topuzovska ${ }^{4}$, Natasha \\ Tolevska ${ }^{1}$, Borislav Kondov ${ }^{1}$ \\ ${ }^{1}$ University Clinic for Thoracic Surgery, Medical Faculty, University "Ss Cyril and Methodis", Skopje, Republic of Macedonija; ${ }^{2}$ University \\ Clinic for Oncology, Medical Faculty, University "Ss Cyril and Methodis", Skopje, Republic of Macedonija; "University Clinic for \\ Anesthesiology and Reanimatology, Medical Faculty, University "Ss Cyril and Methodis", Skopje, Republic of Macedonija; ${ }^{4}$ Univesity Clinic \\ for Infective Disease and Febrile Conditions, Medical Faculty, University "Ss Cyril and Methodis", Skopje, Republic of Macedonija
}

\begin{abstract}
Citation: Kondov G, Crvenova S, Spirovski Z, Trajkovska T, Jovev S, Kondova-Topuzovska I, Tolevska N, Kondov B. Early Complications after Lung Resections at Patients Treated For Lung Cancer with and Without Neoadjuvant Cancer with and Without Neoadjuvan Hemiotheraphy. Maced J Med Sci. 2012 Jul 31 5(2):177-180. http://dx.doi.org/10.3889/ MJMS.1957-5773.2012.0226.

Key words: NSLC; neoadjuvant chemotheraphy; lung resection; complications; only lung resection.

Correspondence: Prof. d-r Goran Kondov MD, $\mathrm{PhD}$. University Clinic for Thoracic and Vascular Surgery, Medical Faculty, Vodnjanska 17, 1109 Skopje, Republic of Macedonija. E-mail: kondov@yahoo.com

Received: 03-Nov-2011: Revised: 12-Dec-2011; Accepted: 22-Feb-2012; Online first: 12-Jun-2012

Copyright: ( 2012 Kondov G. This is an open access article distributed under the terms of the Creative Commons Attribution License, which permits unresticted use, distribution, permits unrestricted use, distribution, and reproduction in any medium, provided author and source are credited.

Competing Interests: The authors have declared that no competing interests exist.
\end{abstract}

\begin{abstract}
Background: Anatomical lung resection offers the best chance of cure for patients with localized lung cancer. Very often late diagnoses, advanced stage of the disease limit radical anatomical surgical resection. Use of neoadjuvant chemotherapy made some of the cases operable, and later they were surgically treated.
\end{abstract}

Aim: to evaluate early (surgical) complications at patients with neoadjuvant therapy.

Material and Methods: We compare 36 patients surgically treated with lung resection, before treated with neoadjuvant chemotherapy ( 3 to 6 cycles with platinum based regiments under protocol) with 42 patients surgically treated without neoadjuvant chemotherapy, in the same period, in the 2009 and 2010.

Results: At the group with neoadjuvant chemotherapy we register more intraoperative and early postoperative complications as: bleeding 10 vs. $7, p=0.63$, changes in lung vessels 3 vs. $0, p=0.8$, prolonged air leak 9 vs. $6, p=0.63$, stump fistula (at pneumectomy patients) 2 vs. $0, p=0.76$, pneumonia 9 vs. $3, p=0.86$, wound infection 2 vs $0, p=0.73$, atelectasis 8 vs. $2, p=0.88$, prolonged pleural drainage 10 vs. $4, p=0.87$. There, also, was no difference in 30 days mortality rate between groups.

Conclusions: Neoadjuvant therapy increased theperioperative complications in this group of patients compared with a similar group undergoing anatomical lung resection in the same institution. The most common complication in patients receiving induction chemotherapy was detected at the group with neoadjuvant chemotherapy. Strategies to prevent these complications will be important, especially if chemotherapy before resection becomes the standard for all patients with non-small cell lung cancer.

\section{Introduction}

Radical anatomical resection of the lung (lobectomy or pneumectomy) for the early stage of NSCLC is method of choice in the treatment [1]. Unfortunately only 10 to $20 \%$ of patients with newly diagnosed lung carcinoma at the end become candidate for lung resection [2].

Use of neoadjuvant hemiotheraphy made some of the cases operable, and later they were surgically treated. Pre-operative (neo-adjuvant) chemotherapy has shown promise in small trials restricted to stage IIIA patients [3-5]. In last time there were many study to use neoadjuvant hemiotheraphy for IB, IIA and IIB stage also [6-12]. However, little is known about the effect of preoperative chemotherapy on surgical stress and postoperative complications associated with surgical intervention.

The aim of this study is to evaluate early (surgical) 
complications at patients with and without neoadjuvant chemotherapy.

\section{Material and Methods}

We compare 36 patients surgically treated with lung resection, before treated with neoadjuvant therapy (3 to 6 cycles platinum based chemotherapy by protocol, giving combination of cisplatin and gemcitabin or ciclofosfamid or taxol) with 42 patients surgically treated without neoadjuvant chemotherapy, in the same period, in the 2009 and 2010. All patients with neoadjuvant chemotherapy received 3-6 cycles of chemotherapy. Patients with downstage were treated surgically. Surgery (lung resection-"wedge excision", lobectomy or pneumectomy) were done 3 to 5 weeks after last chemotherapy. Other patients with progress of the disease were further treated with chemo-radiotherapy. Stage of the lung cancer disease were done using VII revised TNM classification, from 2009. on Table 1.

Basic characteristic of the groups were shown

Table 1: Characteristics of groups which were evaluated.

\begin{tabular}{rccl}
\hline & $\begin{array}{c}\text { Neoadjuvant } \\
+ \text { Surgery }\end{array}$ & Surgery & \\
\hline Sex & $\mathrm{m}-34 \quad \mathrm{f}-2$ & $\mathrm{~m}-38 \quad \mathrm{f}-4$ & $\mathrm{X}^{2}=0.47, \mathrm{~ns}$ \\
Age & 61.2 & 57.14 & $\mathrm{t}=4.9, \mathrm{~ns}$ \\
Tobacco consumer & $34 / 36$ & $41 / 42$ & $\mathrm{X}^{2}=0.68, \mathrm{~ns}$ \\
Histological type & & & \\
$\begin{array}{r}\text { squamous cell } \\
\text { carcinoma }\end{array}$ & 27 & 35 & \\
adeno carcinoma & 8 & 6 & \\
large cell carcinoma & 1 & 1 & \\
Location & & & \\
RUL & 9 & 10 & \\
RML & 1 & 1 & $\mathrm{X}^{2}=1.02, \mathrm{~ns}$ \\
RDL & 8 & 12 & \\
LUL & 10 & 13 & \\
LDL & 8 & 6 & \\
Surgical intervention & & & \\
exploration & 3 & 2 & \\
wedge excision & 2 & 2 & $\mathrm{X}^{2}=0.96, \mathrm{p}=0.65, \mathrm{~ns}$ \\
lobectomy & 25 & 29 & \\
bilobectomy & 2 & 3 & \\
pneumenectomy & 4 & 6 &
\end{tabular}

\section{Results}

Neoadjuvant chemotherapy was used at 34\% patients that were surgically treated at our Clinic. From 100 patients, which were in IIA, IIB, IIIA and IIIB stage that have no contraindications for surgery, that were send to neoadjuvant chemotherapy, at 28\% there were progress of the disease so we lost them for surgery and they were further with chemo-radiotherapy. Twenty four $\%$ of patients stay at same stage, and some of them were candidate for surgery, especially if the starting stage is $\mathrm{II}$, and if there were no other contraindications from cardiac and lung status. At $48 \%$ were detected down

Table 2: Distribution of surgically treated patients after neoadjuvant therapy.

\begin{tabular}{ccccc}
\hline $\begin{array}{c}\text { Before } \\
\text { neoadjuvant } \\
\text { therapy }\end{array}$ & Stage & $\begin{array}{c}\text { After } \\
\text { neoadjuvant } \\
\text { therapy }\end{array}$ & $\begin{array}{c}\text { Candidate for } \\
\text { surgery }\end{array}$ & $\begin{array}{c}\text { Surgically } \\
\text { treated }\end{array}$ \\
$\mathbf{0}$ & IV & 6 & & \\
$\mathbf{4 1}$ & IIIB & 31 & 21 & 1 \\
$\mathbf{3 4}$ & IIIA & 11 & 9 & 2 \\
$\mathbf{1 9}$ & IIB & $\mathbf{2 3}$ & 2 & 12 \\
$\mathbf{6}$ & IIA & 7 & 7 & 6 \\
$\mathbf{0}$ & IB & $\mathbf{1 4}$ & 14 & 9 \\
$\mathbf{0}$ & IA & 7 & 7 & 5 \\
$\mathbf{0}$ & 0 & $\mathbf{1}$ & 1 & 1 \\
\hline 100 & & 100 & 61 & 36 \\
\hline
\end{tabular}

staging, and all this patients were candidate for surgical resection if there were no detected other contraindication. Finally from all this patients surgically were treated only 36 (Table 2).

At the group with neoadjuvant hemiotheraphy we registered more intraoperative and early postoperative complications as: bleeding 10 vs. 7, changes in lung vessels (clinically manifested as rigid, with tendency to
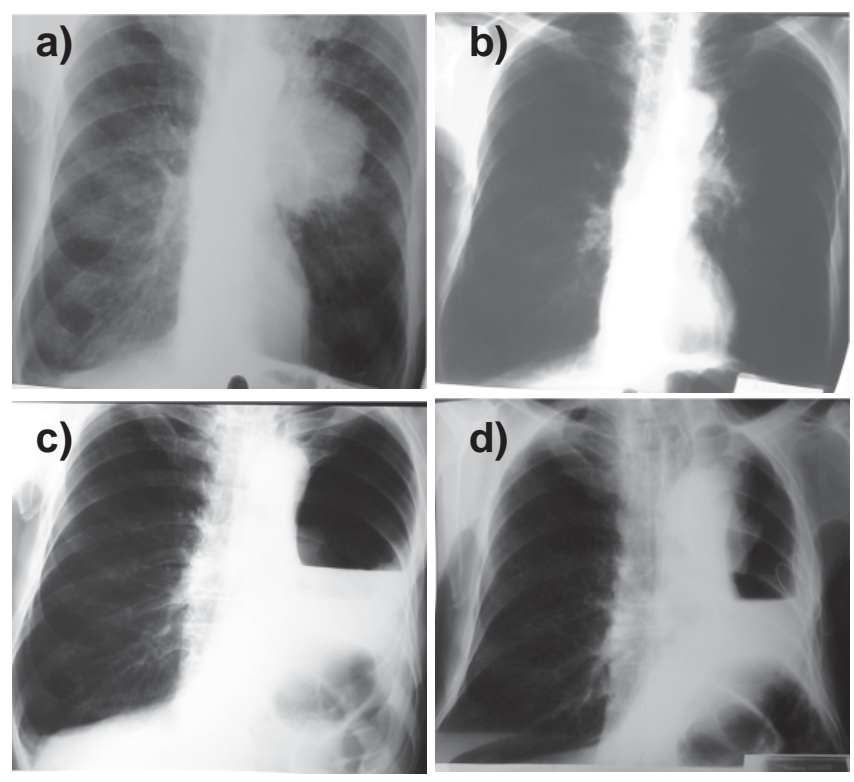

Figure 1: Roentgenography of surgically treated patients after neoadjuvant therapy. a) Before chemotheraphy; b) After chemotheraphy; c) After pneumenectomy; d) After treatment of fistula.

snap, when were dissected, and very difficult is to sowed with atraumatic pollen thread) 3 vs. 0, prolonged air leak 9 vs. 6 , stump fistula (at pneumectomy patients) 2 vs. 0 , pneumonia 9 vs. 3, wound infection 2 vs. 0, athelectasis 8 vs. 2, prolonged pleural drainage 10 vs. 4 (Fig. 1). 
Table 3: Clinical findings of surgically treated patients after neoadjuvant therapy.

\begin{tabular}{lccc}
\hline & $\mathrm{NA}+\mathrm{S}$ & $\mathrm{S}$ & \\
\hline Bleeding & 10 & 7 & $\mathrm{X}^{2}=0.22, \mathrm{p}=0.63, \mathrm{~ns}$ \\
Changes in lung vessels & 3 & 0 & $\mathrm{X}^{2}=0.06, \mathrm{p}=0.83, \mathrm{~ns}$ \\
Prolonged air leak & 9 & 6 & $\mathrm{X}^{2}=0.23, \mathrm{p}=0.63, \mathrm{~ns}$ \\
Stump fistula (at pneumectomy) & $2 / 4$ & $0 / 6$ & $\mathrm{X}^{2}=0.11, \mathrm{p}=0.73, \mathrm{~ns}$ \\
Pneumonia & 9 & 3 & $\mathrm{X}^{2}=0.03, \mathrm{p}=0.86, \mathrm{~ns}$ \\
Wound infection & 2 & 0 & $\mathrm{X}^{2}=0.11, \mathrm{p}=0.73, \mathrm{~ns}$ \\
Athelectas is & 8 & 2 & $\mathrm{X}^{2}=0.02, \mathrm{p}=0.88, \mathrm{~ns}$ \\
Prolonged pleural drainage & 10 & 4 & $\mathrm{X}^{2}=0.02, \mathrm{p}=0.87, \mathrm{~ns}$ \\
Empyema & 8 & 6 & $\mathrm{X}^{2}=0.37, \mathrm{p}=0.54, \mathrm{~ns}$ \\
Dead (30 days) & 3 & 2 & $\mathrm{X}^{2}=0.55, \mathrm{p}=0.47, \mathrm{~ns}$ \\
\hline
\end{tabular}

There, also, was no difference in 30 days mortality rate between groups. All this results were shown on Table 3.

\section{Discusion}

Radical anatomical resection of the lung (lobectomy or pneumectomy) for the early stage of NSCLC is method of choice in the treatment [1]. Unfortunately only 10 to $20 \%$ of patients with newly diagnosed lung carcinoma at the end become candidate for lung resection [2]. Reason for this are histological type ( SCLC), advanced stage (big percent of patients in IIIA and IIIB stage), advanced age of patients and big percent of comorbidites (heart problems, respiratory insufficiency, kidney problems and so on).

Use of neoadjuvant chemotherapy made some of the cases operable, and later they were surgically treated. Pre-operative (neo-adjuvant) chemotherapy has shown promise in small trials restricted to stage IIIA patients [3-5]. In last time there were many studys to use neoadjuvant hemiotheraphy for IB, IIA and IIB stage also [6-12]. Many trials have shown that preoperative chemotherapy for lung cancer is feasible but associated with postoperative morbidity and mortality $[3,11]$. However, little is known about the effect of preoperative chemotherapy on surgical stress and postoperative complications associated with surgical intervention.

We very well know side effect of chemotherapy, which all are temporary, like: diarrhea, temporary hair loss, weight loss, fatigue, depression, nausea and vomiting, anemia. Also we know that is possible appearing heart failure, fatigue, problems with memory, appearing infertility, peripheral neuropathy, osteoporosis, problems with lung fibrosis, damage of kidney and bladder. But little is known about problems during surgery and after that. These side effects from the neoadjuvant chemotherapeutics are nearly always temporary. Most patients are able to continue with their normal activities for all but perhaps 1 or 2 days per month. Many of the side effect were treated with some medications, like metoclopramide (Reglan), ranitidine (Ranital), serotonin antagonists, especially ondansetron (Zofran), Filgrastim (Neupogen), eritropoetin - epoetin alfa (Epogen), giving blood or some derivates from blood (plasma, trombocite mass), antibiotics and so on.

In literature there were many controversies about side effect during surgery and after that at patients with neoadjuvant hemiotheraphy. Authors like Boer, Sunsucke, Roberts, Albain, Venuta, say that in group with preoperative neoadjuvant chemotherapy there were register larger amount of complications, in some series they were statistically significant, and also in some series were detected larger amount of postoperative deaths [3-7]. On other hand authors like Siegenthaler, Perrot, Refai in their evaluations said that there were not significant complications in the group with neoadjuvant hemiotheraphy [8-10].

Chemotherapy induces both a transient and a relatively permanent immune deficit in treated patients. The most common cause of postoperative morbidity and mortality after lung resection is infectious, and complications after that, whether caused by pneumonia. It is reasonable to expect that neoadjuvant chemotherapy could affect the chances of postoperative morbidity and mortality. On the other hand lung resection is among the riskiest of surgical procedures, so it expected to be appeared more frequently complications.

In our examination we detected more complications in the group with preoperative neoadjuvant therapy. But no one complication is statistically significant more frequent in group with neoadjuvant hemiotheraphy. In our series we compare patient with lung cancer, preoperative treated only with hemiotheraphy (no radiotherapy). Some of the complication were minor and need only conservative treatment, mainly treatment of the infection. Treatment of the some complications need prolonged drainage, but at 3 were need reoperation.

Knowing that mainly complications were according disturbed immunity and according appearing infection of the lung, we obviously give two antibiotics per operatively and postoperatively, following parameters of inflammation (leukocyte number, CRP) and respond to that.

Conclusion: Neoadjuvant chemotherapy is giving for systematic treatment of lung cancer. Also at some patients there were detected down staging and is given chance for radical surgical treatment at patients 
where were not indicated at moment of diagnosis of lung cancer.

Complications were more frequent in the group with neoadjuvant hemiotheraphy and surgery, vs. group treated only surgically, but there were not statistically significances for any complication.

Strategies to prevent these complications will be important, especially if chemotherapy before resection becomes the standard for all patients with non-small cell lung cancer.

\section{References}

1. National Comprehensive Cancer Network. Available at http:/ /www.nccn.org.

2. Van Schil P, Hendriks J, De Maeseneer M, Vandenbroeck Ch, Lauwers P. Decision making about operability in non-small cell lung cancer. Acta Chir Belg. 2007;107(5):495-9.

3. Roberts JR, Eutis C, Devore R, Carbone D, Choy H, Johnson $D$. Induction chemotherapy increases perioperative complications in patients undergoing resection for non-small cell lung cancer. Ann Thorac Surg. 2001;72:885-888.

4. Albain KS, Rusch VW, Crowley JJ, Rice TW, Turrisi 3rd AT, Weick JK, Lonchyna VA, Presant CA, McKenna RJ, Gandara DR. Concurrent cisplatin/etoposide plus chest radiotherapy followed by surgery for stage IIIA(N2), and IIIB non-small cell lung cancer. Mature results of southwest oncology group phase II study. J Clin Oncol. 1995;13:1880-1892.

5. Venuta F, Anile M, Diso D, Ibrahim M, De Giacomo T, Rolla M, Liparulo V, Coloni GF. Operative complications and early mortality after induction therapy for lung cancer Eur J
Cardiothorac Surg. 2007;31:714-717.

6. de Boer RH, Smith IE, Pastorino U, O'Brien MER, Ramage F, Ashley S, Goldstraw P. Pre-operative chemotherapy in early stage resectable non-small-cell lung cancer: a randomized feasibility study justifying a multicentre phase III trial- Eur J Cardiothorac Surg. 2004;26:787-791.

7. Endo S, Sato Y, Hasegawa T, Tetsuka K, Otani S, Saito N, Tezuka Y, Sohara Y. Preoperative chemotherapy increases cytokine production after lung cancer surgery. Eur J Cardiothorac Surg. 2004;26:787-791.

8. Siegenthaler MP, Pisters KM, Merriman KW, Roth JA, Swisher SG, Walsh GL, Vaporciyan AA, Smythe WR, Putnam $\mathrm{Jr}$ JB. Preoperative chemotherapy for lung cancer does not increase surgical morbidity. Ann Thorac Surg. 2001;71:11051111.

9. Refai M, Brunelli A, Rocco G, Ferguson MK, Fortiparri SN, Salati M, La Rocca A, Kawamukai K. Does induction treatment increase the risk of morbidity and mortality after pneumonectomy? A multicentre case-matched analysis. Eur J Cardiothorac Surg. 2010;37:535-53.

10. Perrot E, Guibert B, Mulsant P, Blandin S, Arnaud I, Roy P, Geriniere L, Souquet PJ. Preoperative Chemotherapy Does Not Increase Complications After Nonsmall Cell Lung Cancer Resection. Ann Thorac Surg. 2005;80:423-427.

11. Martin J, Ginsberg RJ, Abolhoda A, Bains MS, Downey RJ, Korst RJ, Weigel TL, Kris MG, Venkatraman ES, Rusch VW. Morbidity and mortality after neoadjuvant therapy for lung cancer: the risks of right pneumonectomy. Ann Thorac Surg. 2001;72(4):1149-54.

12. Stolz AJ, Schützner J, Harustiak T, Lischke R, Simonek J, Pafko P. [Impact of neoadjuvant chemotherapy on postoperative complications following neumonectomy].Rozhl Chir. 2009;88(5):225-8. 